\title{
THE ABSORPTION AND EXCRETION OF PENICILLIN FOLLOWING CONTINUOUS INTRAVENOUS AND SUBCUTANEOUS ADMINISTRATION
}

\author{
By LOWELL A. RANTZ AND WILLIAM M. M. KIRBY, wITH THE \\ TECHNICAL ASSISTANCE OF ELIZABETH RANDALL
}

(From the Department of Medicine, Stanford University School of Medicine, San Francisco)

(Received for publication January 13, 1944)

Penicillin, a product of the growth of a fungus, penicillium notatum, has become established as a therapeutic agent of value in the management of various infections, particularly those caused by the pyogenic cocci (1).

Because penicillin is unstable in the presence of acid, it may not be given by mouth and absorption from the duodenum is imperfect. It has, therefore, been administered parenterally in nearly all of the recorded clinical studies. Three routes have usually been used: (1) intermittent intravenous; (2) intermittent intramuscular; and (3) continuous intravenous. Adequate clinical results have been obtained with each but in only one instance have studies been made of the fate of the injected material.

It has been shown (2) that the injection of a single large dose of penicillin, intravenously, was followed by a very rapid rise and fall of the blood level of this substance, so that at the end of 2 hours, the amount remaining was not detectible by the method used. During this interval, about 60 per cent of the injected penicillin appeared in the urine. Absorption was somewhat slower and the blood levels were lower but better maintained following intramuscular administration. Absorption from the subcutaneous tissues was irregular, and the levels reached in the blood were low.

The use of the continuous intravenous drip for the administration of penicillin has been advocated (3). This author has suggested a daily dose of 50,000 units, but has not studied the concentrations of the drug in the blood or urine.

It is the purpose of this report to describe the results of determinations of blood and urine concentrations of penicillin obtained during the study of patients under treatment with this agent, all of whom received penicillin by continuous intravenous or subcutaneous drip.

\section{METHODS AND MATERIALS}

Penicillin concentration. The concentration of penicillin in plasma and urine was determined routinely by a modification of the method previously described (4). In certain instances, the plasma concentration was measured by a photoelectric turbidimetric technic. Both of these methods will be described in detail elsewhere. It is important to bear in mind that both involve dilution technics and are, therefore, subject to considerable error. The exact magnitude of this error has been studied and will be described elsewhere, but may be stated to be approximately \pm 30 per cent.

Blood. Since it has been previously shown (2) that nearly all of the blood penicillin is dissolved in the plasma and very little in the red blood cells, the former material was used in all tests, whole blood being collected aseptically into tubes containing an appropriate amount of sterile sodium citrate. Preliminary tests revealed that this substance does not interfere with the action of penicillin.

Urine. Timed urines were collected, frequently by catheter, and immediately sterilized by Seitz filtration. The concentration of penicillin in each specimen was determined by the modification of the Rammelkamp method mentioned above.

Penicillin solutions.1 The sodium salt of penicillin, obtained as a powder, dehydrated and in vacuo, was dissolved in appropriate amounts of sterile, pyrogen-free isotonic sodium chloride, or 5 per cent dextrose solution. The concentrations most frequently used contained 25, 100 , and 200 units per cc.

Administration. Penicillin solutions of suitable concentration were administered by continuous intravenous or subcutaneous drip in the usual way. Not more than 1,000 cc. were given in 24 hours by the subcutaneous route.

\section{RESULTS}

\section{Blood levels and urinary excretion}

\section{A. Carefully controlled intravenous administration}

A series of experiments was undertaken to determine the plasma levels and the rates of

\footnotetext{
2 The penicillin was provided by the Office of Scientific Research and Development from supplies assigned by the Committee on Medical Research for clinical investigations, recommended by the Committee on Chemotherapeutic and Other Agents of the National Research Council.
} 
urinary excretion of penicillin following its administration by the continuous intravenous route at a carefully controlled rate.

Seven patients, all afebrile primary or secondary syphilitics, were well hydrated for 24 hours before the experiment was begun. The administration of penicillin was started in the morning, with the patient under basal conditions until the conclusion of the experiment. Solutions of penicillin in normal salt solution of a concentration of 25 and 100 units per cc. were prepared and administered by the continuous intravenous route in such a way that 2,500 , $5,000,10,000$, and 20,000 units per hour were given at a rigidly controlled rate. Each level was maintained for a 2-hour period, during the last 30 minutes of which a blood and a timed urine specimen were obtained. The results of these experiments are presented in Table $I$.

It will be observed that the results are, on the whole, quite consistent in the light of the inherent error in the methods of determining the concentration of penicillin. The latter factor makes it most profitable to discuss these experiments on the basis of the last section of the table, which presents the average of all the values obtained in 7 experiments.

Plasma concentration. The plasma concentration of penicillin at the various rates of administration was determined in 4 instances by

TABLE I

Absorption and excretion of penicillin following continuous intravenous administration

\begin{tabular}{|c|c|c|c|c|c|c|c|c|c|}
\hline \multirow{2}{*}{ Name } & \multirow{2}{*}{$\begin{array}{c}\text { Penicillin } \\
\text { administered }\end{array}$} & \multicolumn{3}{|c|}{ Concentration of penicillin } & \multirow{2}{*}{$\begin{array}{l}\text { Urine } \\
\text { excretion }\end{array}$} & \multirow{2}{*}{\multicolumn{2}{|c|}{ Excretion of penicillin }} & \multirow{2}{*}{$\begin{array}{l}\text { Plasma } \\
\text { cleared of } \\
\text { penicillin } \\
\text { (dilution) }\end{array}$} & \multirow{2}{*}{$\begin{array}{l}\text { Plasma } \\
\text { cleared of } \\
\text { penicillin } \\
\text { (turbi- } \\
\text { dimetric) }\end{array}$} \\
\hline & & Plasma & Plasma & Urine & & & & & \\
\hline $\mathbf{F r}$ & $\begin{array}{c}\text { units per } \\
\text { hour } \\
2,500 \\
5,000 \\
10,000 \\
20,000\end{array}$ & $\begin{array}{l}\text { units } \\
\text { per cc. } \\
0.04 \\
0.1 \\
0.2 \\
0.5\end{array}$ & $\begin{array}{c}\text { units } \\
\text { per cc. } \\
0.04 \\
0.14 \\
0.25 \\
0.48\end{array}$ & $\begin{array}{r}\text { urits } \\
\text { per cc. } \\
4.0 \\
60.0 \\
200.0 \\
100.0\end{array}$ & $\begin{array}{c}\text { cc. per } \\
\text { minule } \\
7.8 \\
1.7 \\
1.4 \\
4.5\end{array}$ & $\begin{array}{c}\text { units per } \\
\text { minute } \\
31.2 \\
102.0 \\
280.0 \\
450.0\end{array}$ & $\begin{array}{c}\text { units per } \\
\text { hour } \\
1,875 \\
6,100 \\
16,800 \\
25,000\end{array}$ & $\begin{array}{l}c c . \text { per } \\
\text { minute } \\
\\
1,020 \\
1,400 \\
900\end{array}$ & $\begin{array}{l}\text { cc. per } \\
\text { minute }\end{array}$ \\
\hline $\mathbf{B r}$ & $\begin{array}{r}2,500 \\
5,000 \\
10,000\end{array}$ & $\begin{array}{l}0.04 \\
0.06 \\
0.10\end{array}$ & $\begin{array}{l}0.04 \\
0.06 \\
0.12\end{array}$ & $\begin{array}{r}4.0 \\
20.0 \\
20.0\end{array}$ & $\begin{array}{l}6.2 \\
4.3 \\
5.0\end{array}$ & $\begin{array}{r}24.8 \\
86.0 \\
100.0\end{array}$ & $\begin{array}{l}1,490 \\
5,150 \\
6,000\end{array}$ & $\begin{array}{l}1,430 \\
1,000\end{array}$ & \\
\hline Le & $\begin{array}{r}2,500 \\
5,000 \\
10,000 \\
20,000\end{array}$ & $\begin{array}{l}0.06 \\
0.06 \\
0.20\end{array}$ & & $\begin{array}{r}5.0 \\
10.0 \\
50.0 \\
20.0\end{array}$ & $\begin{array}{l}8.7 \\
6.5 \\
2.0 \\
7.2\end{array}$ & $\begin{array}{r}43.5 \\
65.0 \\
100.0 \\
144.0\end{array}$ & $\begin{array}{l}2,650 \\
3,900 \\
6,000 \\
8,650\end{array}$ & $\begin{array}{r}1,080 \\
1,670 \\
720\end{array}$ & \\
\hline Gr & $\begin{array}{r}2,500 \\
5,000 \\
10,000 \\
20,000\end{array}$ & $\begin{array}{l}0.06 \\
0.10 \\
0.20 \\
0.50\end{array}$ & $\begin{array}{l}0.07 \\
0.11 \\
0.25 \\
0.32\end{array}$ & $\begin{array}{r}5.0 \\
50.0 \\
20.0 \\
100.0\end{array}$ & $\begin{array}{r}7.7 \\
2.6 \\
11.0 \\
5.2\end{array}$ & $\begin{array}{r}28.5 \\
130.0 \\
220.0 \\
520.0\end{array}$ & $\begin{array}{r}2,310 \\
7,800 \\
13,200 \\
31,200\end{array}$ & $\begin{array}{r}640 \\
1,300 \\
1,100 \\
1,040\end{array}$ & \\
\hline De & $\begin{array}{r}2,500 \\
5,000 \\
10,000 \\
20,000\end{array}$ & $\begin{array}{l}0.06 \\
0.10 \\
0.20 \\
0.50\end{array}$ & $\begin{array}{l}0.06 \\
0.12 \\
0.36 \\
0.42\end{array}$ & $\begin{array}{r}5.0 \\
6.0 \\
5.0 \\
20.0\end{array}$ & $\begin{array}{l}11.7 \\
13.7 \\
15.2 \\
15.4\end{array}$ & $\begin{array}{r}58.5 \\
82.0 \\
76.0 \\
308.0\end{array}$ & $\begin{array}{r}3,500 \\
4,920 \\
4,560 \\
18,500\end{array}$ & $\begin{array}{l}970 \\
820 \\
380 \\
615\end{array}$ & \\
\hline En & $\begin{array}{r}2,500 \\
5,000 \\
10,000 \\
20,000\end{array}$ & $\begin{array}{l}0.05 \\
0.10 \\
0.20 \\
0.40\end{array}$ & & $\begin{array}{r}5.0 \\
6.0 \\
20.0 \\
40.0\end{array}$ & $\begin{array}{r}6.1 \\
8.3 \\
10.6 \\
16.9\end{array}$ & $\begin{array}{r}30.5 \\
49.8 \\
212.0 \\
676.0\end{array}$ & $\begin{array}{r}1,830 \\
2,980 \\
12,700 \\
40,500\end{array}$ & $\begin{array}{r}610 \\
498 \\
1,060 \\
1,690\end{array}$ & \\
\hline Sm & $\begin{array}{r}2,500 \\
5,000 \\
10,000 \\
20,000\end{array}$ & $\begin{array}{l}0.05 \\
0.06 \\
0.10 \\
0.20\end{array}$ & & $\begin{array}{r}6.0 \\
10.0 \\
10.0\end{array}$ & $\begin{array}{l}18.5 \\
14.5 \\
16.1\end{array}$ & $\begin{array}{l}111.0 \\
145.0 \\
161.0\end{array}$ & $\begin{array}{l}6,660 \\
8,700 \\
9,660\end{array}$ & $\begin{array}{r}1,850 \\
1,450 \\
805\end{array}$ & \\
\hline $\begin{array}{l}\text { Average } \\
\text { values }\end{array}$ & $\begin{array}{r}2,500 \\
5,000 \\
10,000 \\
20,000\end{array}$ & $\begin{array}{l}0.05 \\
0.08 \\
0.15 \\
0.38\end{array}$ & $\begin{array}{l}0.05 \\
0.11 \\
0.24 \\
0.41\end{array}$ & & & $\begin{array}{r}37.8 \\
89.5 \\
162.0 \\
376.0\end{array}$ & $\begin{array}{r}\mathbf{2}, 270 \\
\mathbf{5}, 370 \\
\mathbf{9}, 720 \\
22,580\end{array}$ & $\begin{array}{r}755 \\
1,120 \\
1,080 \\
989\end{array}$ & $\begin{array}{l}755 \\
815 \\
735 \\
915\end{array}$ \\
\hline
\end{tabular}




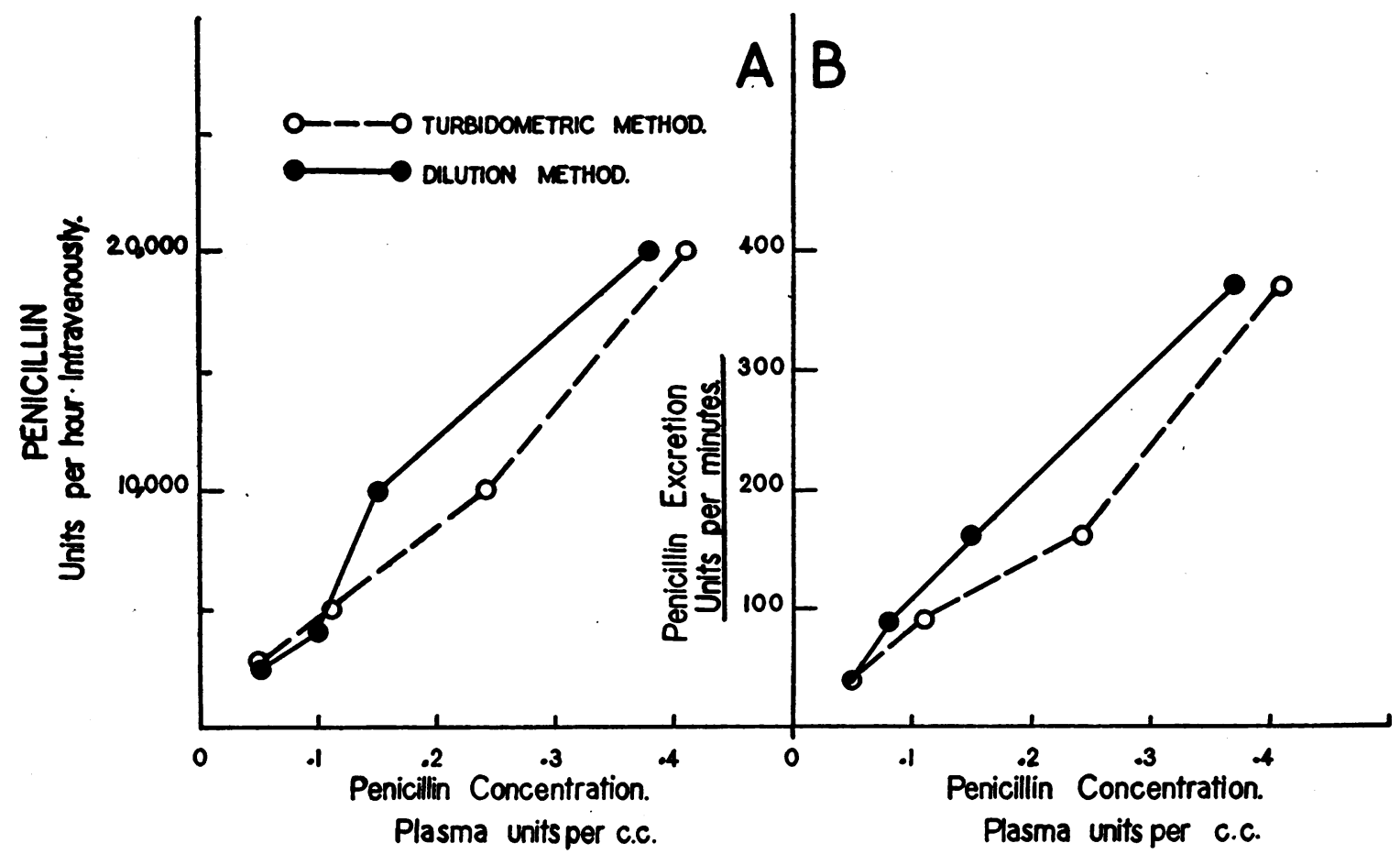

Fig. 1. A. Relationship Between the Amount of Penicillin Injected and the Plasma Concentration

B. Relationship Between the Rate of Urinary Excretion of Penicillin and the

Plasma Concentration

the turbidimetric method and in 7 by the dilution technic. It will be observed that there were large variations between the plasma levels obtained in different subjects, but that there is a close correlation between the average values obtained by the two methods.

The continuous intravenous infusion of 2,500 units of penicillin per hour induced a concentration of this substance in the plasma of 0.05 units per cc.; 5,000 units, 0.08 to 0.11 units per cc.; 10,000 units, 0.15 to 0.24 units per cc. ; and 20,000 units, 0.38 to 0.41 units per cc.

Figure 1A, in which the plasma concentrations obtained by the two methods are plotted against the rate of administration, reveals that there is an approximately linear relationship between these two factors.

Urinary excretion. The data presented in Columns 6 and 7 of Table $I$ indicate that penicillin is rapidly excreted in the urine. Figure $1 B$ demonstrates that the rate of excretion is proportional to the plasma concentration. The average hourly rates of excretion are equal to the amount administered. No evidence of destruction of penicillin in the tissues was discovered.

Plasma clearance. In Columns 8 and 9, the average amounts of plasma cleared of penicillin by the kidneys, in cc. per minute, are presented. The calculations have been made using the plasma concentrations obtained by the dilution and turbidimetric methods separately.

From 755 to $1,120 \mathrm{cc}$. of plasma were cleared per minute. These are rates comparable to those obtained when studies have been made of substances believed to be excreted by the renal tubules and are many times greater than the clearance of $130 \mathrm{cc}$. per minute to be expected by glomerular filtration alone (5).

The plasma clearances of penicillin at the lowest and highest rates of administration were comparable, suggesting that the maximum rate of tubular excretion, or $\mathrm{Tm}$ (5), of this substance had not been reached.

It is also of interest to point out that severalfold differences in the rate of urinary flow, in certain subjects, were not associated with varia- 
TABLE II

Excretion of penicillin in febrile patients

\begin{tabular}{|c|c|c|c|c|c|c|c|c|c|}
\hline \multirow{2}{*}{$\begin{array}{l}\text { Patient } \\
\text { number }\end{array}$} & \multirow{2}{*}{ Dose } & \multirow{2}{*}{ Route } & \multirow{2}{*}{ Temp. } & \multicolumn{2}{|c|}{ Penicillin } & \multirow{2}{*}{$\begin{array}{c}\text { Urine } \\
\text { excretion }\end{array}$} & \multirow{2}{*}{\multicolumn{2}{|c|}{ Penicillin excretion }} & \multirow{2}{*}{$\begin{array}{c}\text { Penicillin } \\
\text { plasma } \\
\text { clearance }\end{array}$} \\
\hline & & & & Plasma & Urine & & & & \\
\hline & $\begin{array}{c}\text { units per } \\
\text { hour }\end{array}$ & & ${ }^{\circ} \mathrm{C}$. & \multicolumn{2}{|c|}{ units per cc. } & $\begin{array}{l}\text { cc. per } \\
\text { minute }\end{array}$ & $\begin{array}{l}\text { units per } \\
\text { minute }\end{array}$ & $\begin{array}{l}\text { unils per } \\
\text { hour }\end{array}$ & $\begin{array}{l}\text { cc. per } \\
\text { minute }\end{array}$ \\
\hline $\begin{array}{c}1 \\
2 \\
3 \\
4 \\
5 \\
6 \\
\text { Average }\end{array}$ & $\begin{array}{l}\mathbf{4}, 160 \\
\mathbf{8}, 320 \\
\mathbf{8}, 320 \\
\mathbf{8}, 320 \\
\mathbf{8}, 320 \\
\mathbf{8 , 3 2 0}\end{array}$ & $\begin{array}{l}\text { Subcut. } \\
\text { Subcut. } \\
\text { Intraven. } \\
\text { Intraven. } \\
\text { Intraven. } \\
\text { Subcut. }\end{array}$ & $\begin{array}{l}38.5 \\
39.0 \\
39.0 \\
38.5 \\
38.5 \\
38.5\end{array}$ & $\begin{array}{l}0.033 \\
0.10 \\
0.14 \\
0.20 \\
0.20 \\
0.10\end{array}$ & $\begin{array}{r}5.0 \\
10.0 \\
33.0 \\
70.0 \\
40.0 \\
10.0\end{array}$ & $\begin{array}{r}4.1 \\
4.7 \\
8.0 \\
6.5 \\
8.5 \\
24.2\end{array}$ & $\begin{array}{r}20.5 \\
47.0 \\
260.0 \\
455.0 \\
350.0 \\
242.0\end{array}$ & $\begin{array}{r}1,230 \\
2,820 \\
15,600 \\
27,300 \\
21,000 \\
14,550\end{array}$ & $\begin{array}{r}620 \\
470 \\
1,850 \\
2,270 \\
1,750 \\
2,420 \\
1,560\end{array}$ \\
\hline
\end{tabular}

tions in the plasma clearance of penicillin. This is in accord with observations made on other materials known to be excreted by the renal tubules.

\section{B. Effect of fever}

It has been shown that the plasma clearance of substances excreted by the renal tubules is closely related to the rate of blood flow to the kidney and that the latter may be increased by the injection of pyrogens (6). It was, therefore, of interest to determine the rate of excretion of penicillin in febrile patients. The results of 6 such experiments are presented in Table II. In 3 patients, the material was administered by continuous subcutaneous drip and, in 3 , by continuous intravenous drip.

Definite conclusions cannot be drawn from these few observations, but it should be pointed out that the average plasma clearance in the presence of fever was approximately 50 per cent greater in these febrile individuals than in the previously described afebrile group.

\section{Plasma levels during routine administration}

The concentration of penicillin in the plasma following its administration at rigidly controlled rates by the continuous intravenous route has been described. Many determinations were also made of the amount of penicillin in plasma, obtained following the administration of this agent, intravenously and subcutaneously in various amounts, when patients were under routine treatment. At such times, the rate of infusion of the penicillin solution was under the careful supervision of experienced nurses and ward of- ficers, but was not controlled as it was in the previous studies.

The results of these observations are presented in Table III. Considerable variation was discovered to exist between determinations of the

TABLE III

Plasma concentrations of penicillin obtained during routine administration by continuous intravenous and subcutaneous drip

\begin{tabular}{|c|c|c|c|c|}
\hline \multirow{3}{*}{$\begin{array}{l}\text { Penicillin dosage } \\
\text { in } 24 \text { hours }\end{array}$} & \multicolumn{4}{|c|}{ Plasma concentration } \\
\hline & \multicolumn{2}{|c|}{$\begin{array}{c}\text { Individual } \\
\text { determinations }\end{array}$} & \multicolumn{2}{|c|}{ Average } \\
\hline & $\begin{array}{l}\text { Intra- } \\
\text { venous }\end{array}$ & $\begin{array}{c}\text { Sub- } \\
\text { cutaenous }\end{array}$ & $\begin{array}{l}\text { Intra- } \\
\text { venous }\end{array}$ & $\begin{array}{l}\text { Sub- } \\
\text { cutaneous }\end{array}$ \\
\hline 100,000 units & $\begin{array}{l}0.40 \\
0.20 \\
0.10 \\
0.10 \\
0.20 \\
0.10 \\
0.06 \\
0.04 \\
0.04\end{array}$ & $\begin{array}{l}\text { units } \\
0.05 \\
0.06 \\
0.05 \\
0.04 \\
0.03 \\
0.05 \\
0.05 \\
0.05 \\
0.06 \\
0.06\end{array}$ & cc. & 0.05 \\
\hline 200,000 units & $\begin{array}{l}0.10 \\
0.20 \\
0.33 \\
0.14 \\
0.20 \\
0.20 \\
0.20 \\
0.40 \\
0.50 \\
0.10 \\
0.10\end{array}$ & $\begin{array}{l}0.10 \\
0.05 \\
0.10 \\
0.20 \\
0.10\end{array}$ & 0.22 & 0.11 \\
\hline 400,000 units & $\begin{array}{l}0.20 \\
0.50 \\
0.40 \\
0.60\end{array}$ & & 0.42 & \\
\hline
\end{tabular}


plasma level in different patients and in the same individual at different times. It will be observed that the average plasma level induced by the administration of 100,000 units intravenously in 24 hours was 0.13 units per cc.; 200,000 units, 0.22 units per cc.; and 400,000 units, 0.42 units per cc. These values closely approximate those obtained when penicillin was given at rigidly controlled rates by the same route.

The infusion of penicillin subcutaneously was not associated with the development of plasma levels of this magnitude. The average concentration obtained during the administration of 100,000 units in a 24-hour period by this route was only 0.05 units per cc.; during the administration of 200,000 units, only 0.11 units per cc.

\section{DISCUSSION}

The observations just described have demonstrated that predictable plasma concentrations of penicillin will be obtained when penicillin is administered by continuous intravenous drip under rigidly controlled conditions. The infusion of 2,500 units per hour (60,000 units per day) may be expected to induce a concentration of approximately 0.05 units per cc.; 5,000 units per hour (120,000 units per day), 0.10 units per cc.; 10,000 units per hour (240,000 units per day), 0.20 units per cc.; 20,000 units per hour $(480,000$ units per day), 0.40 units per cc. When studies were made of plasma levels obtained during the routine treatment of patients by the intravenous route, they were found to approximate these values closely.

If penicillin was administered subcutaneously, the plasma levels were about 50 per cent lower than those observed during the treatment of patients by the intravenous route. The reason for this discrepancy is not apparent but it is possible that the creation of a reservoir of penicillin in the subcutaneous tissues permits its destruction before it is absorbed.

These studies have also clarified the mode of excretion of penicillin. It has beensuggested (7) that the renal tubules must play an important rôle in the clearance of penicillin from the plasma and blocking of the tubular excretory mechanism by the simultaneous injection of diodrast and penicillin has been attempted, with partial success.
The calculations presented above, based upon studies in afebrile patients under basal conditions, in whom from 750 to $1,120 \mathrm{cc}$. of plasma were cleared of penicillin per minute, definitely proves the tubular excretion of this substance, since the average amount cleared by glomerular filtration alone could have been only $130 \mathrm{cc}$. per minute (5).

These values are higher than those obtained for the average diodrast clearance, $688 \mathrm{cc}$. per minute (5), and suggest that the intravenous injection of penicillin may increase the renal blood flow in a manner similar to that induced by the injection of pyrogens (6). It is not proper, however, to draw this conclusion from so few observations, uncorrected for surface area or sex. It is logical to assume, however, that the renal blood flow and the penicillin plasma clearance will be increased in the febrile patient. That this is the case is suggested by the study of patients with fever described above, in whom the penicillin plasma clearance was 50 per cent greater than in the group of individuals observed under basal conditions.

The plasma clearance does not fall with the maximum plasma concentration of penicillin obtained in these experiments, which indicates that the upper limit of tubular excretion of this substance has not been reached. This was to have been expected since the normal renal tubules may excrete $50 \mathrm{mgm}$. of diodrast iodine per minute (5) and, at the maximum rates recorded here, less than $1 \mathrm{mgm}$. of pure penicillin per minute was being cleared.

Variations in the minute volume of urine have been shown here to have no effect on the rate of excretion of penicillin which is in accord with the observations of others using substances excreted by the renal tubules and in contrast to those in which such chemicals as urea and the sulfonamides were studied $(5,8)$.

Penicillin administered by the continuous intravenous route is quantitatively excreted by the kidney. No destruction in the tissues was demonstrated.

The optimal concentration of penicillin in the plasma and tissues for the treatment of various infections has not yet been determined but, in accord with the available evidence (9), it is probable that a plasma level of 0.20 to 0.30 units per 
cc. is adequate to control severe staphylococcal infections and 0.05 to 0.1 units per cc. may be sufficient to cure infections caused by the hemolytic streptococcus, pneumococcus, and gonococcus.

By the intravenous route, 200,000 to 400,000 units per day should result in plasma levels satisfactory for the treatment of severe staphylococcal infections. Penicillin may be administered by continuous subcutaneous drip in such instances if intravenous therapy is impractical, but the observations presented here definitely indicate that much larger daily doses should be used. By either route, 100,000 to 200,000 units per day should be sufficient for the management of hemolytic streptococcus, pneumococcus, and gonococcus infections.

Only many further detailed studies will determine the optimal mode of administration and dosage of penicillin.

\section{SUMMARY AND CONCLUSIONS}

1. The absorption and excretion of penicillin during continuous intravenous and subcutaneous administration has been studied.

2. Predictable plasma levels were obtained, those following intravenous being higher than those following subcutaneous infusion.

3. Penicillin was removed from the plasma by the kidney at rates which indicate that the renal tubular excretory mechanism was principally involved in this process.
4. The relationship of these observations to the use of penicillin in the treatment of human infections is discussed.

\section{BIBLIOGRAPHY}

1. Keefer, C. S., and others, Penicillin in the treatment of infections. A report of 500 cases. J. A. M. A., 1943, 122, 1217.

2. Rammelkamp, C. H., and Keefer, C. S., The absorption, excretion and distribution of penicillin. J. Clin. Invest., 1943, 22, 425.

3. Herrell, W. E., Further observations on the clinical use of penicillin. Proc. Staff Meet., Mayo Clin., 1943, 18, 65.

4. Rammelkamp, C. H., A method for determining the concentration of penicillin in body fluids and exudates. Proc. Soc. Exper. Biol. and Med., 1942, $51,95$.

5. Smith, H. W., Goldring, W., and Chasis, H., The measurement of the tubular excretory mass, effective blood flow and filtration rate in the normal human kidney. J. Clin. Invest., 1938, 17, 263.

6. Chasis, H., Ranges, H. A., Goldring, W., and Smith, H. W., The control of renal blood flow and glomerular filtration in normal man. J. Clin. Invest., 1938, 17, 683.

7. Rammelkamp, C. H., and Bradley, S. E., Excretion of penicillin in man. Proc. Soc. Exper. Biol. and Med., 1943, 53, 30.

8. Peterson, O. L., Goodwin, R. A., Jr., and Finland, M., Observations on the urinary excretion of sulfadiazine. J. Clin. Invest., 1943, 22, 659.

9. Rammelkamp, C. H., and Keefer, C. S., Penicillin: Its antibacterial effect in whole blood and serum for the hemolytic streptococcus and Staphylococcus aureus. J. Clin. Invest., 1943, 22, 649. 